\title{
Implementation Lean Manufacturing Method of Plywood Manufacture Company
}

\author{
Jastine Koh and Moses Laksono Singgih \\ Department of Technology Management, Institut Teknologi Sepuluh Nopember, Surabaya \\ e-mail: Jastine.tin93@gmail.com, moseslsinggih@ie.its.ac.id
}

\begin{abstract}
Abstrak-The Plywood company in this study was able to produce $6,000 \mathrm{~m} 3$ / year of plywood, but during 2018 and 2019 this company was only able to provide $2,905.14 \mathrm{~m} 3 /$ year and 1,120.73 m3/year. Production in 2018 and 2019 is far below the production capacity. This research will apply the lean manufacturing concept in the production process of a plywood company. This research uses value stream mapping (VSM), value stream analysis tools (VALSAT), process activity mapping (PAM), Pareto diagrams, and root cause analysis. It is found extreme categories that occur in many processes, namely processing production and inventory. The recommendations given are to reduce employees and provide adequate storage. The future state VSM shows that a change in a lead time of $68 \%$, and the reduction of the production process is 248.18 minutes.
\end{abstract}

Keywords-Lean Manufacturing, VSM, VALSAT, Root Cause Analysis.

\section{INTRODUCTION}

$\mathrm{C}$ OMMENCING Increased industrial competition in Indonesia makes companies compete to improve company performance. To compete with other companies, the company must be efficient and minimal waste in its production process. To achieve dynamic company performance and minimal waste, the company apply lean manufacturing methods to maximize value for customers and increase company profitability by eliminating production processes that give no added cost.

The plywood company, which in this research study has not yet maximized production performance. This company has a production capacity of $6,000 \mathrm{~m} 3$ / year, but in 2018 and 2019 , production capacity is only at 2,905.14 $\mathrm{m} 3$ / year and $1,120.73 \mathrm{~m} 3 /$ year. The production results are not optimal because there is a waste in the production process, which is processing raw materials into finished goods by $50 \%-70 \%$, as listed in the following Table 1 .

In addition to wastage in the production process, this company also needs to make adjustments to the production of employees' salaries. Table 2 . To show salary costs almost the same from 2017 to 2019, even with decreasing production results. The following Table 2. compares product results with full salary costs.

So through this research, researchers want to find the causes of waste that occur y examing the flow of the production process, starting from the purchased raw material to the finished products delivered to consumers. Also, this research will look for the root causes of problems that occur during the production process and provide recommendations for appropriate improvement.

\section{RESEARCH METHOD}

This study will use data from observations and distribution of questionnaires to production employees. Then draw value stream mapping to describe the problem and uses root cause analysis to find the root cause of the problem and eliminate it. The results of this study will reduce the non-added value during the production processes, suggest improvements to the root causes of problems in the production process, and are expected to have further improvements after applying the proposed improvement results.

\section{RESULT AND DISCUSSIONS}

\section{A. Value Stream Mapping Current State}

The following diagram will display the value stream mapping current state which is the production process flow that has been carried out by the company. Through the mapped production process flow from Figure 1. a questionnaire was made to ranked seven wastes that could occur during the production process. After the results of the questionnaire have been recapitulated, the results of the questionnaire are used for calculations in the selection of mapping tools. Here are the results of calculating the selection of mapping tools. Based on Table 3. process activity mapping is used to carry out further analysis for the elimination of activities that give no added value to consumers.

\section{B. Eliminate NVA activities and maximize VA}

Through the results of the process activity mapping, we get the time of production activities on operations, transportation, inspection, storage, and delay. Also, this method can determine the time of events that adds value, or that's must be eliminated in the production process. The following results from making process activity mapping current state. Based on Table 4., six activities do not provide added value with a time of 248.18 minutes. So by eliminating non-value added activities, the lead time will reduced by $68 \%$ in the process of 1 wooden block. The following Table 5 shows events that give no added value activity to consumers.

\section{Critical waste mapping}

Based on the data questionnaries from twenty production employees, they calculate the essential waste. Based on the ranking of seven waste and percentage cumulative waste below $80 \%$ (Figure 2.), four critical wastes are prioritized to 
2nd International Conference on Industrial and System Engineering (IConISE) and

7 th Annual Conference on Industrial and System Engineering (ACISE) 2020

July $22^{\text {nd }}-23^{\text {rd }} 2020$, Surabaya, Indonesia

Table 1.

Processing Raw Materials into Finished Goods (m3)

\begin{tabular}{ccccc}
\multicolumn{5}{c}{ Processing Raw Materials into Finished Goods $(\mathrm{m} 3)$} \\
\hline \hline Year & LOG & WIP & Finished Good & \%Waste LOG to WIP and Finished Good \\
\hline 2017 & $14,741.20$ & $5,257.63$ & 242.50 & $62.69 \%$ \\
2018 & $7,112.16$ & $2,748.35$ & 156.79 & $59.15 \%$ \\
2019 & $4,406.41$ & 969.83 & 150.89 & $74.57 \%$ \\
\hline \hline
\end{tabular}

Table 2.

Comparison of product results with detailed salary costs for 2017-2019

\begin{tabular}{ccccc}
\multicolumn{5}{c}{ Comparison of product results with detailed salary costs for $2017-2019$} \\
\hline Unit & 2017 & 2018 & 2019 \\
WIP + Finished Good & $\mathrm{m} 3$ & $5,500.13$ & $2,905.14$ & $1,120.72$ \\
Salary & $\mathrm{Rp}$ & $4,614,498,505$ & $4,219,566,775$ & $4,887,389,211$ \\
\hline \hline
\end{tabular}

Tabel 3.

Result of Value Stream Mapping Tools

\begin{tabular}{|c|c|c|c|c|c|c|c|}
\hline Waste in Manufacture & PAM & RM & $\begin{array}{l}\mathrm{PVF} \\
\end{array}$ & QFM & DAM & DPA & PS (a) Volume (b) Value \\
\hline Overproduction & 39 & 117 & - & 39 & 117 & 117 & - \\
\hline Waiting Time & 270 & 270 & 30 & - & 90 & 90 & - \\
\hline Transportation & 324 & - & - & - & - & - & 36 \\
\hline Processing & 486 & - & 162 & 54 & - & 54 & - \\
\hline Inventory & 147 & 441 & 147 & - & 441 & 147 & 49 \\
\hline Motion & 333 & 37 & - & - & - & - & - \\
\hline Defect & 20 & - & - & 180 & - & - & - \\
\hline Total & 1.619 & 865 & 339 & 273 & 648 & 408 & 85 \\
\hline
\end{tabular}

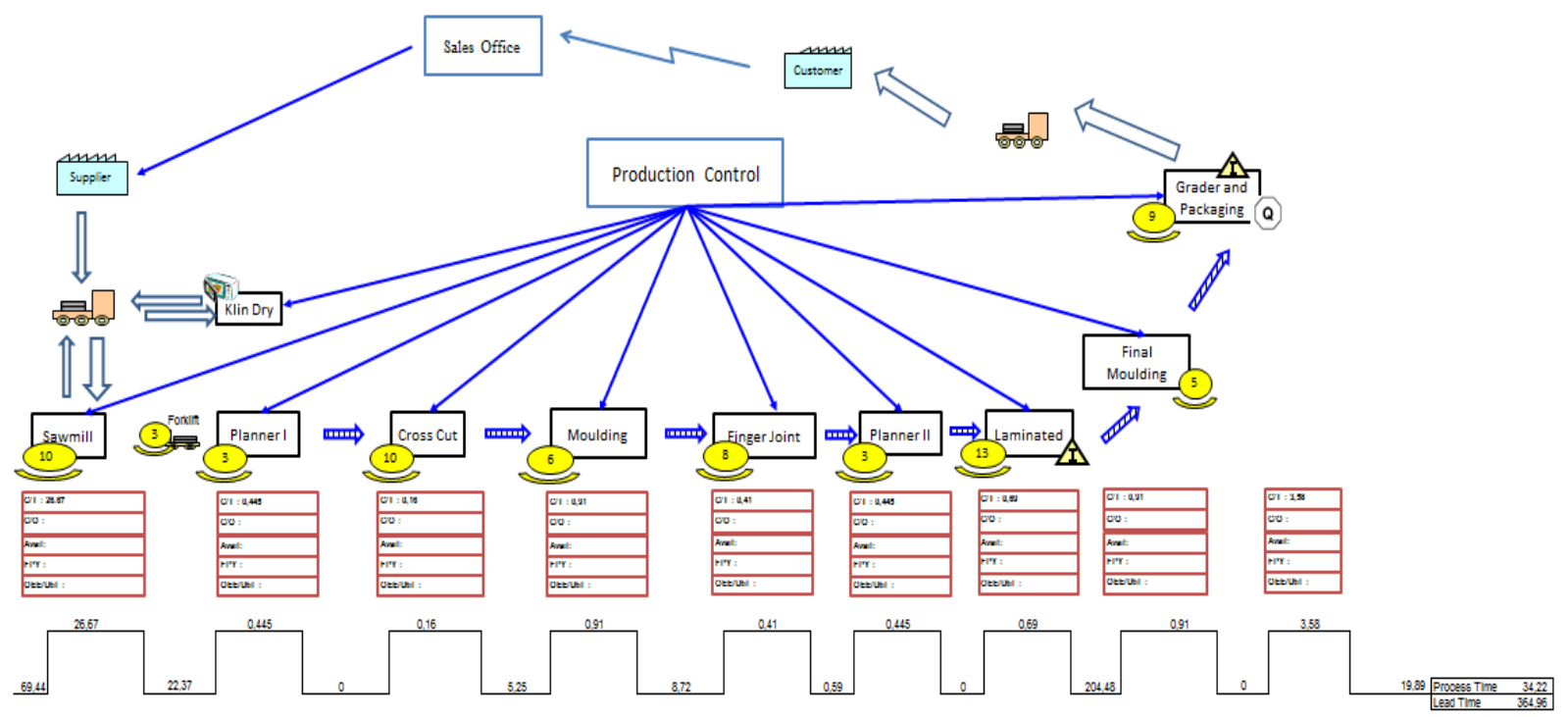

Figure 1. Values Stream Mapping Current State

find the root of the problem. Those four wastes are processing, inventory, overproduction, and motion.

Through waste priority, a mapping of the possibilities and impacts of the problems obtained through root cause analysis is carried out, and seven issues are categorized in extreme areas, namely:

- Lack of supervision

- There is no clarity on the production output that must be produced

- There is a lack of employee overtime

- There is no warehouse for storing goods

- Stockpiling causes the production floor to narrow

- Inventories that accumulate often damaged

- There are several employees in the same work floor which causes inefficiency in work

Concerning the seven problems, there are two proposed improvements given after analyzing the issues, namely:
- Reduction of labor examined through the capacity of engine performance and output results that can be generated during one hour of the production process.

Based on Table 6. The number of employees required for production is obtained through proper machine needs. The company only requires the production of the 71 wooden blocks within one-hour of the production process; therefore, a reduction in machinery and employees is made to maximize production performance, the reduction in employees can also reduce the salary that must be paid by the company. One machine just needed two employees, except sawmill one machine can be handled by four employees and also grader and packing one machine only required one employee to manage the machine.

- Eliminate inventory buildup that occurs in every corner of the factory by making a storage rack and facilitate the 
2nd International Conference on Industrial and System Engineering (IConISE) and

7th Annual Conference on Industrial and System Engineering (ACISE) 2020

July $22^{\text {nd }}-23^{\text {rd }} 2020$, Surabaya, Indonesia

Table 4.

Results of PAM Recapitulation and Value Added Activity

\begin{tabular}{|c|c|c|c|c|c|}
\hline Activity & Total & Minute & Activity & Total & Minute \\
\hline Operation & 17 & 40.55 & VA & 13 & 34.23 \\
\hline Transport & 3 & 57.42 & NNVA & 9 & 82.56 \\
\hline Inspeksi & 3 & 24.04 & NVA & 6 & 248.18 \\
\hline Storage & 3 & 22.60 & Total & 28 & 364.96 \\
\hline Delay & 2 & 224.99 & & & \\
\hline Total & 28 & 369.61 & & & \\
\hline
\end{tabular}

Table 5.

Non-Value Added Activity

\begin{tabular}{|c|c|c|c|}
\hline No & Activity & Type & NVA \\
\hline 1 & Waiting for the Kiln Dry process & $\mathrm{D}$ & 21.60 \\
\hline 2 & Gather the remaining small pieces of wood blocks & $\mathrm{S}$ & 5.24 \\
\hline 3 & Collect molding shavings & $\mathrm{S}$ & 8.72 \\
\hline 4 & Choose small pieces of wood that are still good and compose on the machine & $\mathrm{O}$ & 0.59 \\
\hline 5 & Laminated wood beams pressed & $\mathrm{D}$ & 203.39 \\
\hline 6 & Wrapped Finished goods that are ready to be sent & $\mathrm{S}$ & 8.64 \\
\hline
\end{tabular}

Table 6.

Calculation of Employee Reduction

\begin{tabular}{|c|c|c|c|c|c|c|c|}
\hline Activity & Block/Minute & Q Block/ Hour & Q Machine & Block/ Machine & Current Employee & Future Machine & Future Employee \\
\hline Sawmill A & 4,83 & 12 & 1 & 300 & 4 & 1 & 4 \\
\hline Sawmill B & 0,54 & 112 & 5 & 560 & 6 & 1 & 2 \\
\hline Planner I & 0,89 & 67 & 2 & 134 & 6 & 1 & 2 \\
\hline Cross cut & 0,16 & 378 & 3 & 1.134 & 10 & 1 & 2 \\
\hline Moulding & 1,82 & 32 & 4 & 128 & 10 & 3 & 6 \\
\hline Finger Joint & 1 & 60 & 1 & 60 & 8 & 2 & 4 \\
\hline Laminated & 1,78 & 33 & 4 & 132 & 15 & 3 & 6 \\
\hline Grader dan Packing & 3,58 & 16 & 9 & 144 & 9 & 5 & 5 \\
\hline
\end{tabular}

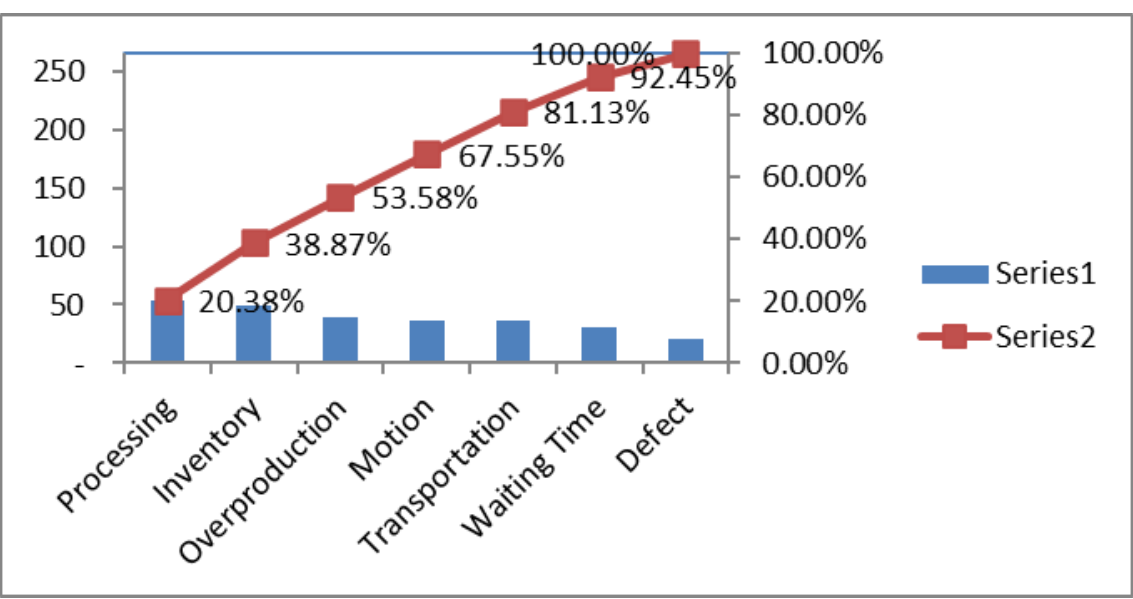

Figure 2. Pareto Diagram

process of taking finished goods. The following is a display rack that will be used as a storage place for finished products.

The shelves will consist of five stacks, each stack will have 100 wooden blocks and 25 shelves will be needed for storage due to 12,500 wooden blocks required for a month. Although the costs incurred for the purchase of shelves are quite expensive, the existence of storage shelves will benefit the company. The benefit is the working space of the factory is wider so that it smoothens the production process, the collection of goods becomes more comfortable and there is no accumulation of goods that get damaged (Figure 3 ).

\section{Value Stream Mapping Future State}

Based on the proposed improvements in the NVA elimination process and root cause analysis, the lead time in the production process is reduced by 248.18 minutes, and the reduction of employees in the production process. The following Figure 4. will display the future state value stream mapping.

\section{CONCLUSION}

This study's results are proposed improvements to reduce the number of employees by 37 people, from the reduction of the employee salary costs can also be reduced by Rp $129,500,000 /$ month. Also, the making of a storage rack is a proposed improvement so that factory working space becomes more comfortable and the storage area tidier to facilitate the forklift movement. By eliminating non-valueadded, the lead time is reduced by $68 \%$ for the future state map. So the production process was reduced to 248.18 minutes.. 
2nd International Conference on Industrial and System Engineering (IConISE) and

7 th Annual Conference on Industrial and System Engineering (ACISE) 2020

July $22^{\text {nd }}-23^{\text {rd }} 2020$, Surabaya, Indonesia

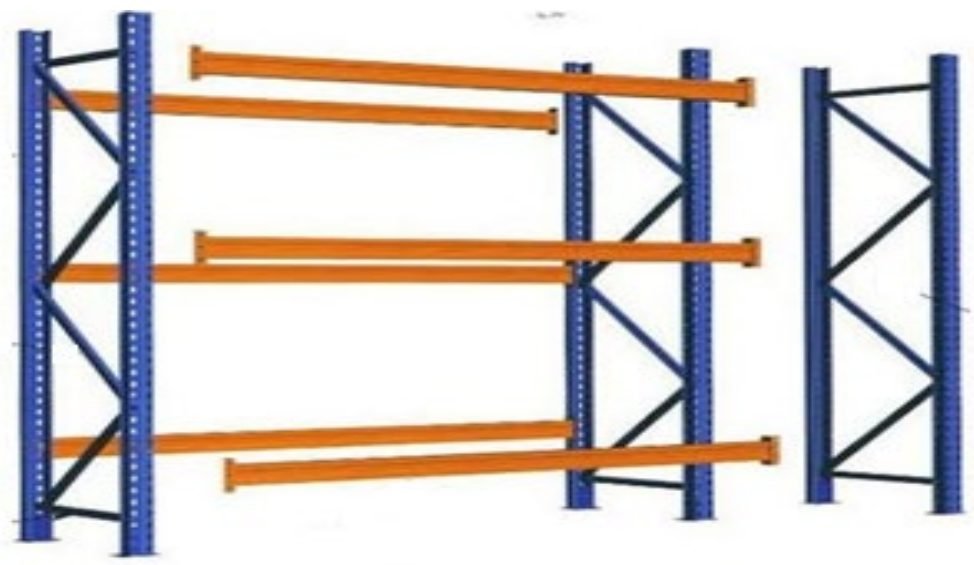

Figure 3. Finished goods storage rack

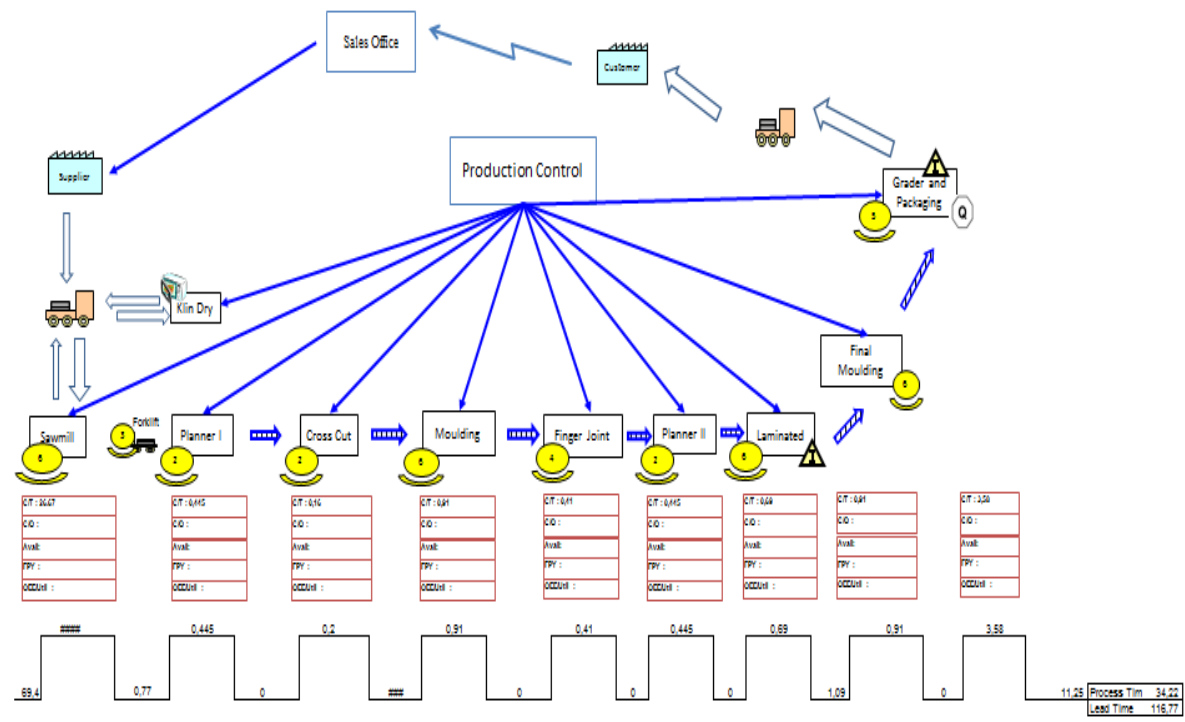

Figure 4. Value Stream Mapping Future State

\section{REFERENCES}

[1]. Askin, R.G., and Goldberg, J., 2001. Design And Analysis Of Lean Production Systems. John Wiley \& Sons, Inc, United States.

[2]. Fernando, Yosua Caesar, and Sunday Noya. 2014. "Optimasi Lini Produksi Dengan Value Stream Mapping Dan Value Stream Analysis Tools." Jurnal Ilmiah Teknik Industri 13(2):125-33.

[3]. Hines and Taylor, D. 2000. "Going Lean. Lean Enterprise Research Center Cardiff Business School." Reliability Centered Maintenance (RCM) II", 2nd Ed. New York: Industrial Press.

[4]. Kumar, T. Saravana, P. R. Soumya, V. Minu Manjari, R. E. Aishvariya, and N. Akalya. 2017. "Implementation of Lean Manufacturing Tools in Garment Industry." IJLTEMAS VI(iii):3943.

[5]. Manzouri, Malihe, Mohd Nizam Ab-Rahman, Che Rosmawati Che Mohd Zain, and Ezad Azraai Jamsari. 2014. "Increasing Production and Eliminating Waste through Lean Tools and Techniques for Halal Food Companies." Sustainability (Switzerland) 6(12):9179-9204.

[6]. Ohno, T. 1988. Toyota Production System: Beyond Large-Scale Production. Productivity Press.

[7]. Rooney, S. A. \& Rooney, J. J. 2005. "Lean Glossary." Quality Progress.

[8]. Rother, Mike dan Shook, John. 2009. "Learning to See: Value Stream Mapping to Create Value and Eliminate Muda." Cambridge: Lean Enterprise Institute.

[9]. Rother, Mike. 2010. Rother M. (2010). "Toyota Kata: Managing People for Improvement, Adaptiveness and Superior Results." McGraw-Hill. McGraw-Hill.
[10]. S.K.P.N, Silva. 2012. "Applicability of Value Stream Mapping (VSM) in the Apparel Industry in Sri Lanka." International Journal of Lean Thinking 3(1).

[11]. Shomad, Mifthahus; Rakhmawati dan Supriyanto. 2009. "Identifikasi Waste Pada Produksi Kayu Lapis Dengan Pendekatan Lean Manufacturing Untuk Meningkatkan Kualitas Proses Produksi (Studi Kasus : PT Sumber Mas Indah Plywood)." Agrointek 4:49-59.

[12]. Wilson, Lonnie. 1966. How to Impelement Lean Manufacturing. Vol. 112. United State: The British Journal of Psychiatry.

[13]. Womack, James P. dan Jones, Daniel T. 2003. "Lean Thinking, Banish Waste and Create Wealth in Your Corporation." Simon \& Schuster UK Ltd. 